\title{
Persepsi dan preferensi penggunaan skincare pada perempuan milenial dalam perspektif komunikasi pemasaran
}

\author{
Wifka Rahma Syauki', Diyah Ayu Amalia Avina² \\ ${ }^{1,2}$ Universitas Brawijaya, Malang, Indonesia
}

\begin{abstract}
ABSTRAK
Perkembangan konsumsi masyarakat mengalami kenaikan setiap tahunnya, salah satunya adalah jumlah penyedia jasa atau produsen, terutama produk skincare. Produsen tidak hanya terdiri dari brand impor, namun brand lokal, yang saat ini jumlahnya semakin banyak. Tidak bisa dipungkiri kemudahan teknologi juga menjadi salah satu pemantik kebutuhan pasar. Kemudahan akses internet membuat konsumen dihadapkan dengan banyaknya pilihan produk. Kompleksitas produk beriringan dengan kompleksitas keputusan pembelian konsumen, terutama konsumen perempuan sebagai mayoritas pengguna produk skincare. Keputusan pembelian menjadi sebuah proses panjang yang dilakukan konsumen. Konsumen melakukan persepsi terhadap pesan persuasif yang diberikan produk, Selanjutnya persepsi tersebut menjadi penentu preferensi konsumen akan produk tersebut. Beberapa pesan persuasif yang dipersepsi adalah tentang isu lingkungan, komposisi produk, country of origin, dan animal testing. Tujuan penelitian ini adalah untuk mengetahui persepsi dan preferensi konsumen perempuan milenial dalam keputusan pembelian produk skincare. Metode yang digunakan adalah deskriptif kualitatif, dengan melakukan wawancara kepada perempuan pengguna skincare. Hasil penelitian menyatakan bahwa dalam menentukan keputusan pembelian produk skincare terdiri dari dua indikator, aspek keyakinan akan produk dan aspek kebutuhan akan produk. Aspek keyakinan meliputi pertimbangan identitas brand yang sudah punya "nama besar" dan banyak digunakan. Indikator kebutuhan ada pada bagaimana skincare tersebut dapat memenuhi kebutuhan terutama dalam mengatasi permasalahan konsumen. Selain itu, faktor utama yang menjadi alasan perempuan memilih skincare juga dari persepsi komunikasi akan produk. Persepsi akan sebuah produk dari segi merek, kandungan, nilai sosial, juga menjadi faktor penentu preferensi konsumen.
\end{abstract}

Kata-kata kunci: perilaku konsumen; persepsi komunikasi; preferensi pembelian; milenial; skincare

\section{Perceptions and preferences of the use of skincare in millennial female in marketing communication perspectives}

\begin{abstract}
The development of public consumption is increasing every year. One of the popular product nowadays is skincare product. Popularity increases not only for imported brands, but also local brands. It is undeniable that the ease of technology is also the stimulus of market needs. The internet access gives consumer a large selection of product and makes the purchasing decision process more complex, especially for female consumers. A purchase decision is a long process by consumers, from perceiving product persuasive messages to determining preferences for choosing a products. Some perceived persuasive message is about environmental issues, composition of the product, country of origin, and animal testing. The purpose of this study was to determine how perceptions and preferences of millennial female consumers in purchasing decisions for skincare products. The research used a descriptive qualitative method, by conducting interviews with female consumers. The results shows that, in determining the decision to purchase skincare products, consumers consider two indicators, product confidence and need for products. Aspects of belief include the consideration of brand identity that already has a "big name" and is widely used. Indicators of need are on how the skincare can meet the needs, especially in overcoming consumer problems. In addition, the main factor that is the reason female choose skincare is also from the perception of communication about the product. Perception of a product in terms of brand, content, and social value also the determinants of consumer preferences.
\end{abstract}

Keywords : consumer behavior, perception; purchase preferences, millennial, skincare

Korespondensi: Wifka Rahma Syauki, M.Si. Universitas Brawijaya. Jln. Veteran, Malang, Jawa Timur 65145.Email:wifka@ub.ac.id 


\section{PENDAHULUAN}

Telah menjadi rahasia umum bahwasanya komunikasi berperan penting dalam bidang pemasaran. Komunikasi pemasaran salah satu aspek yang penting dari keseluruhan proses pemasaran suatu perusahaan dan juga dianggap sebagai penentu utama dalam kegagalan maupun kesuksesan perusahaan. Melalui komunikasi pemasaran, perusahaan misalnya mempromosikan produk agar tujuan yang telah ditentukan dapat tercapai (Suryana, Zein, Sumartias, \& Gemiharto, 2019). Dalam konteks yang lebih lengkap, komunikasi pemasaran terpadu merupakan kunci keberhasilan pemasaran baik produk maupun jasa .

Prinsip komunikasi pemasaran menyatakan bahwa pencapaian tujuan perusahaan sangat dipengaruhi dari bagaimana perusahaan atau produsen mampu memahami kebutuhan dan keinginan konsumen serta mempu memenuhinya dibanding pesaingnya. Maka dari itu akan menjadi faktor yang menentukan apabila produsen mampu memahami karakteristik dari perilaku konsumen mereka (Shimp, 2014; Simamora, 2008)

Pada praktiknya, ternyata gender harus sangat diperhatikan dalam komunikasi pemasaran. Perempuan merupakan pelaku konsumsi yang paling berpengaruh terhadap ranah komunikasi pemasaran. Survey yang dilakukan Muhtar Kent, CEO The Coca Cola Company (2010) menunjukkan bahwa perempuan di seluruh dunia melakukan pembelanjaan sebanyak 20 trilyun dolar. Maka dari itu memahami perilaku konsumen perempuan merupakan sebuah informasi krusial bagi produsen untuk memenuhi keinginan konsumen.

Salah satu fungsi produk bagi konsumen adalah untuk memenuhi keinginan tampil percaya diri. Penampilan, bentuk tubuh, dan kontrol fisik menjadi pusat perhatian akan identitas individu secara visual (Shilling, 2007b). Oleh karena itu, komoditas produk utama yang menjadi konsumsi perempuan akan identitas diri adalah penggunaan skincare. Produk ini dikonsumsi karena perempuan Indonesia berusaha untuk menjaga kecantikan diri, terutama secara fisik. Pentingnya penggunaan skincare dapat dilihat dari survey yang dilakukan MarkPlus, Inc dan ZAP Beauty Index (ZAP Beauty Index, 2018) di gambar 1.

Gambar 1 menunjukkan bahwa mayoritas perempuan memulai konsumsi skincare sejak berusia kurang dari 13 tahun. Survey juga menunjukkan pengguna skincare utama adalah konsumen perempuan pada rentang usia $19-23$ tahun, usia yang masuk pada kategori generasi milenial.

Perilaku konsumen perempuan milenial juga dibarengi dengan literasi informasi yang 


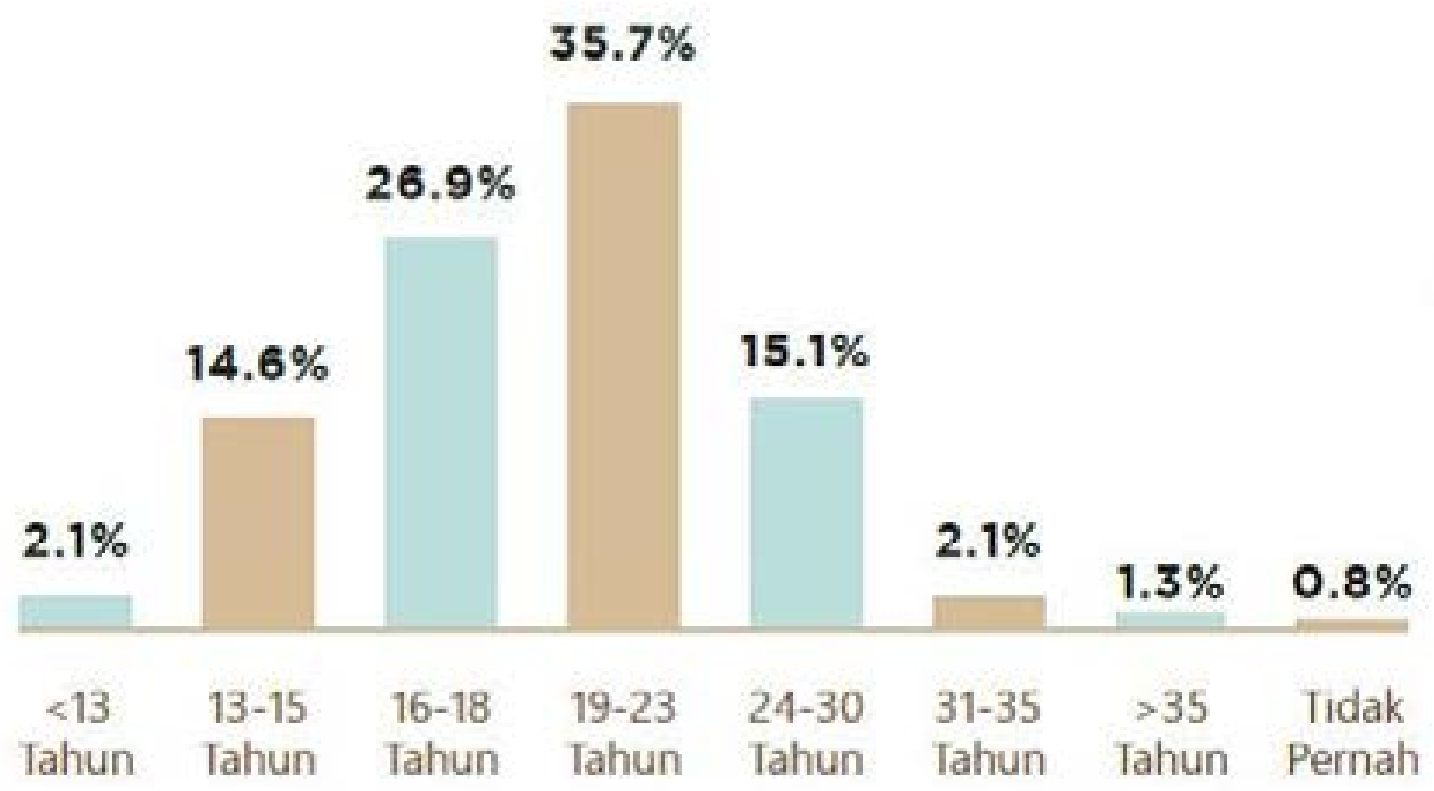

Sumber: Zap Beauty Index, 2018

\section{Gambar 1 Waktu Pertama Kali Penggunakan Skincare}

saat ini semakin meningkat. Adanya integritas koneksi internet dan jejaring sosial menjadi sebuah kemudahan bagi konsumen untuk mengetahui informasi dari skincare yang akan ia beli. Terlebih generasi milenial merupakan generasi yang mengandalkan media digital dalam pencarian informasi (Utomo, Lubis, \& Sudradjat, 2012)

Tema-tema riset terkait perilaku konsumen telah banyak dilakukan dan dibangun dari beberapa rangkaian perilaku. Sayangnya, tematema yang diangkat cenderung tidak dinamis. Tema riset umumnya sekitar dari proses keputusan pembelian, sampai pada perilaku setelah pembelian. Hal yang membedakan umumnya hanya terletak pada konteks atau tema produk yang dipakai konsumen. Terkait tema produk skincare, banyak konten baik itu di laman resmi atau media sosial, terkait perilaku menggunakan skincare. Salah satu konten populer mengenai skincare adalah tentang sepuluh langkah penggunaan skincare ala korea, tips perawatan kulit, tips agar kulit bersih dan bercahaya, kulit halus, dan bebas jerawat (Kwon, 2018)

Pesan iklan yang mampu membujuk dan memengaruhi konsumen untuk membeli produk merupakan sebuah kekuatan persuasi. Iklan merupakan sebuah bentuk pesan komunikasi yang salah satu fungsinya adalah mengubah persepsi konsumen terhadap atribut suatu merek (Hermanto, 2007). Persepsi merupakan inti dari 
komunikasi, sebuah proses di mana individu mengorganisasikan, dan menginterpretasi pesan untuk memberikan arti (Robbins, 2015). Sebuah pesan yang menarik mengenai sebuah produk menjadi salah satu kesan sensori yang ditangkap konsumen dan selanjutnya mereka interpretasi serta beri makna (Shimp, 2014). Semakin banyaknya pesan atau iklan akan produk skincare, memunculkan pula banyaknya variasi dari persepsi produk itu sendiri.

Fenomena ini, bagi pemasar, menjadi sebuah peluang dan inovasi untuk masuk dalam persaingan pasar. Bagi konsumen, hal ini juga memicu perubahan dalam proses keputusan pembelian. Alternatif produk yang ada di pasar menjadikan konsumen harus mempertimbangkan banyak faktor, misalnya isu label, isu animal testing dan komposisi produk.

Kondisi dimana setiap hari manusia terpapar berbagai bahan kimia dalam kesehariannya melalui produk konsumen menjadikan beberapa produk harus memenuhi persyaratan produk tersebut diuji. Tes uji coba ini biasanya dilakukan pada hewan untuk memastikan produk aman. Pada faktanya, Uni Eropa sendiri mayoritas tes digunakan untuk uji racun pada hewan. Namun seiring berkembangnya isu sosial ini ada beberapa perubahan salah satunya Amandemen ke-7 Cosmetics Directive dan $R E A C H$. Peraturan ini mendorong peneliti untu mengembangkan dan mengadopsi uji coba selain pada hewan (Westmoreland \& Holmes, 2009)

Adanya nilai sosial pada produk menciptakan sebuah keterlibatan situasional pada konsumen (Pratiwi, 2019). Melakukan seleksi pemilihan produk yang sesuai dengan preferensi, maka konsumen merasa ikut terlibat pula dengan kepedulian sosial. Hal tersebut dapat diartikan apabila konsumen membeli produk yang peduli akan lingkungan maka, ia juga telah melakukan perubahan sosial. Preferensi konsumen dapat diartikan dengan kesukaan, pilihan terhadap suatu hal yang lebih disukai konsumen. Preferensi ini muncul melalui proses persepsi konsumen terhadap sebuah produk (Wono, 2018)

Selain itu, asal negara skincare juga menjadi pertimbangan akan citra sebuah produk. Country of origin merupakan atribut keputusan pembelian konsumen. Kotler Keller menyatakan bahwa sikap dan keyakinan pembeli akan suatu negara menjadi salah satu proses pengambilan keputusan akan suatu produk (Pangestuti \& Devika, 2018)

Terkait isu komposisi produk juga menjadi fokus dalam preferensi pemilihan produk. Bersamaan dengan meningkatnya penekanan pada penampilan eksternal dan konsumsi produk kecantikan, baik untuk kesehatan tubuh, dan dengan lingkungan fisik eksternal telah muncul sebagai tren konsumen terkini (Shilling, 
2007a).

Pembahasan mengenai konsumen tidak terlepas dari perilakunya. Perilaku konsumen adalah perilaku yang ditampilkan konsumen dalam mencari, membeli, menggunakan, mengevaluasi, dan membuang produk dan layanan yang mereka harapkan akan memuaskan kebutuhan mereka (Schiffman, 2010). Perilaku konsumen berfokus pada bagaimana konsumen individu dan keluarga atau rumah tangga membuat keputusan untuk menghabiskan sumber daya mereka yang tersedia (waktu, uang, usaha) pada barang-barang yang terkait dengan konsumsi. Keputusan itu termasuk apa yang mereka beli, mengapa mereka membelinya, kapan mereka membelinya, di mana mereka membelinya, seberapa sering mereka membelinya, seberapa sering mereka menggunakannya, bagaimana mereka mengevaluasinya setelah pembelian, dampak evaluasi tersebut pada pembelian di masa depan, dan bagaimana mereka membuangnya.

Konsumen memiliki karakter yang dinamis. Meskipun secara ilmu, perilaku konsumen bukanlah hal yang baru untuk dipelajari, namun selalu ada hal baru yang akan ditemukan dari konsumen ketika ekonomi juga berkembang. Konsumen Indonesia yang didominasi oleh masyarakat yang usianya masih muda dan melek internet (Priyandana, 2018)

Kotler dan Keller menyebutkan ada banyak Faktor yang memberikan pengaruh pada perilaku konsumen, antara lain sebagai berikut; (1) faktor budaya terdiri atas budaya, subbudaya, dan kelas sosial. (2) faktor sosial terdiri atas kelompok referensi, keluarga, peran, dan status. (3) faktor pribadi terdiri atas usia, pekerjaan, keadaan ekonomi, kepribadian, dan gaya hidup. (4) faktor psikologis terdiri atas motivasi, persepsi, pembelajaran, dan memori (Shree \& Nagabushanam, 2018)

Topik perilaku konsumen merupakan hal yang akan selalu menjadi topik perbincangan dalam ranah komunikasi pemasaran. Maka dari itu, tantangan yang dihadapi oleh semua pemasar saat ini adalah bagaimana mempengaruhi perilaku pembelian konsumen dalam mendukung produk atau layanan mereka. Oleh karena itu, pengetahuan tentang perilaku pembelian dengan menyoroti psikologi tentang bagaimana konsumen berpikir, merasakan, berargumen, dan memilih di antara alternatif yang ada (misalnya, merek, produk, dan distributor) adalah sesuatu yang penting. Bukan hanya itu, lingkungan konsumen (misalnya, budaya, keluarga, dan media) memengaruhi konsumen, motivasi konsumen, serta penggunaan strategi berbeda untuk produk yang berbeda, dapat mengarahkan pada pemahaman tentang bagaimana pemasar dapat meningkatkan kampanye pemasaran mereka untuk lebih efektif dalam menjangkau 
konsumen (Kavaratzis, 2009)

Dalam melakukan pengambilan keputusan, konsumen memiliki proses yang dilalui, proses tersebut dimulai dengan adanya masalah yang dihadapi konsumen, misalnya seorang ibu rumah tangga yang menyadari kurangnya daya tampung pada mesin cuci yang ia miliki. Proses selanjutnya adalah pencarian informasi, ibu rumah tangga mulai dengan bertanya kepada tetangga mengenai mesin cuci yang dimiliki serta besarnya kapasitas dari mesin cuci tersebut. Proses dilanjutkan dengan evaluasi beberapa informasi yang ia peroleh. Proses ini dimulai dengan melakukan perbandingan terhadap beberapa jenis mesin cuci yang ada di toko-toko eletronik dengan berpedoman pada rekomendasi yang diperoleh. Mempertimbangkan reputasi merek dan kecanggihan teknologi dari mesin cuci tersebut, maka proses dilanjutkan dengan pemilihan produk yang sesuai dengan kebutuhannya (Shree \& Nagabushanam, 2018)

Keputusan pembelian mencakup suatu pilihan di antara dua atau lebih tindakan atau perilaku alternatif. Sementara itu, dalam membuat pertimbangan untuk membeli suatu produk, konsumen menggunakan pertimbangan layaknya sebuah spektrum warna (Peter, 2013). Konsumen yang kompeten mungkin memiliki keyakinan subyektif dan obyektif yang lebih besar dalam kemampuan mereka untuk menangani informasi.
Saat melakukan keputusan pembelian, salah satu tahap yang dilalui konsumen adalah bagaimana ia mempersepsi produk tersebut. Kualitas akan produk juga menjadi preferensi dalam memutuskan pembelian. Persepsi akan kualitas disebut dengan perceived quality; Perceived quality adalah persepsi akan kualitas atau keunggulan produk yang ada di benak konsumen. Persepsi akan kualitas dari konsumen akan keunggulan produk merupakan inti dari kerangka ekuitas merek. Hal ini menjadi alasan konsumen untuk membeli produk dan memungkinkan produk untuk melakukan diferensiasi dengan produk pesaingnya (Listiana, 2012)

Persepsi akan kualitas juga melibatkan pada beberapa isu yang menjadi faktor preferensi atau kesukaan konsumen. Adanya atribut intrinsik serta ekstrinsik yang menjadi pembeda merek satu dengan lainnya. Atibut intrinsik adalah atribut terkait fisik produk, seperti warna, rasa, aroma, bentuk, dan penampilan. Atribut ekstrinsik adalah aspek yang tidak terkait pada fisik produk, misalnya nama merek, tanda kualitas, harga, dan informasi produksi. Terdapat tujuh dimensi yang mempengaruhi kesan akan kualitas sebuah produk. Tujuh dimensi tersebut meliputi; kinerja, karakteristik produk, sesuai dengan spesifikasi, keandalan, ketahanan, pelayanan, dan hasil akhir. Salah satu faktor kesan kualitas pada produk skincare 
bisa meliputi isu country of origin, animal cruelty, isu lingkungan, dan kualitas produk sendiri (Listiana, 2012).

Persepsi akan country of origin (COO) merupakan asosiasi mental dan keyakinan yang dipicu oleh suatu negara (Kotler \& Keller, 2012). Pemasar juga memperhatikan terkait sikap dan persepsi konsumen akan asal negara suatu produk. COO sendiri merupakan salah satu asumsi ekstrinsik yang mempengaruhi konsumen dalam memutuskan pembelian, salah satunya pada produk skincare. Penelitian tentang $C O O$ sudah berlangsung sejak tahun 1965. Untuk pertama kalinya, Nagashima pada tahun 1960 mengemukakan konsep COO. Sedangkan Schooler pada tahun 1965 melakukan penelitian tentang COO Effect untuk pertama kalinya. Terkait definisi istilah country of origin memiliki beberapa pemahaman yang sama, seperti misalnya Badri, Davis and Davis memahami efek $C O O$ sebagai efek "made in". Hal menarik tentang penelitian $\mathrm{COO}$ adalah bahwa mayoritas studi dilakukan pada produk konsumen daripada produk jasa (Phau, 2010).

Istilah lain yang mengikuti perkembangan topik-topik country of origin adalah country of design, country of manufacture, country of assembly, dan country of part di mana semua istilah tersebut menunjukkan bahwa beberapa perusahaan global dan transnasional tidak lagi melakukan keseluruhan rangkaian produksi di negaranya. Bisa saja perancangan dilakukan di Korea, namun pembuatan bisa di China dan komponen didatangkan dari Korea.

Dengan perspektif komunikasi pemasaran, citra negara dapat dibagi menjadi tiga tingkat; (1) Overall country image (citra negara keseluruhan); keseluruhan dari ide, kepercayaan, dan kesan akan negara tertentu sebagai hasil dari evaluasi dan persepsi konsumen. Persepsi ini meliputi kelebihan dan kekurangan negara. (2) Aggregate product country image (citra negara asal produk keseluruhan); keseluruhan perasaan kognitifyangmerupakan asosiasi dengan produk dari negara tertentu. Produk yang berasal dari Jepang dipersepsi sebagai produk berteknologi tinggi, asosiasi produk dengan harga murah dilekatkan pada buatan Cina, sedangkan produk dengan daya tahan tinggi berasal dari Jerman. (3) Specific product country image (citra negara asal dilihat pada kategori produk tertentu); merupakan keseluruhan perasaan kognitif yang diasosiasikan dengan spesifikasi produk dari negara tertentu (Demirbag, Sahadev, \& Mellahi, 2010).

Faktor COO yang digunakan untuk mengetahui persepsi konsumen terhadap produk terdiri dari tiga komponen; country beliefs, people affect, dan desire interaction. Country beliefs, yaitu keyakinan calon konsumen tentang perkembangan industri serta kemajuan teknologi yang dimiliki oleh negara asal dari 
merek sebuah produk. Faktor keberhasilan sebuah negara secara umum menjadikan faktor kepercayaan akan negara menjadi salah satu hal yang mempengaruhi perilaku konsumen (Larosche, 2005). Komponen selanjutnya adalah people affect, yaitu tanggapan konsumen terhadap pengaruh dari masyarakat negara asal merek berasal. Selain negara asal, masyarakat asal negara pembuat produk juga mempengaruhi pembelian. Misalnya Korea dengan semakin popular keberadaan artisnya menjadikan konsumen akan mempertimbangkan lebih untuk memilih sebuah produk. Komponen terakhir adalah Desire Interaction, yaitu keinginan konsumen untuk membangun hubungan dengan negara asal merek produk. Setelah kondisi umum asal negara dan juga masyarakatnya, maka semakin membuat konsumen ingin menjalin hubungan yang lebih dengan asal negara.

Ketiga komponen tersebut menunjukkan bahwa asal negara suatu produk menjadi sebuah perhatian besar bagi konsumen. Hal ini berimplikasi pula bagi negara pembuat produk untuk selalu memberikan citra positif akan produk. Lebih jauh lagi, isu COO ini juga menjadi isu bersama bagi para pemasar untuk menekankan asal negara sebagai kekuatan produknya (Larosche, 2005)

Mampu membaca keinginan konsumen merupakan hal penting bagi pemasar untuk mampu mengkomunikasikan identitas dan nilai dari produk mereka. Motivasi konsumen perlu ditingkatkan sehingga pembeli potensial akan memberikan pertimbangan yang serius (Putra \& Ghozali, 2018). Perilaku keputusan pembelian konsumen tersebut merupakan salah satu hal yang rumit dipahami. Ada konsumen yang mengevaluasi informasi dengan cara yang komplek, namun ada pula konsumen yang memberikan keputusan dengan pertimbangan yang sederhana.

Berdasarkan penjelasan di atas maka peneliti melihat adanya urgensi untuk mengetahui bagaimana proses keputusan pembelian produk skincare yang dilakukan perempuan milenial. Proses yang ingin diteliti adalah dari bagaimana tahap persepsi akan pesan persuasif produk yang menjadi poin preferensi atau kesukaan konsumen sehingga melakukan proses pembelian. Maka dari itu, tujuan penelitian ini adalah untuk mengetahui bagaimana persepsi dan preferensi konsumen perempuan milenial dalam keputusan pembelian produk skincare.

\section{METODE PENELITIAN}

Penelitian ini menggunakan paradigma konstruktivis yag berasumsi bahwa kenyataan merupakan hasil dari konstruksi manusia (Neuman, 2014). Penelitian dengan paradigma konstruktivis memandang pengetahun sebagai hasil konstruksi dan hasil pengalaman dari 
fakta. Konstruksi realitas dikonstruksi melalui interaksi sosial serta nilai-nilai budaya dan norma historis yang berlaku di kehidupan individu (Cresswell, 2013).

Paradigma ini sesuai untuk mengetahui bagaimana persepsi komunikasi dan perilaku konsumen berdasarkan pengalaman subyektifnya. Selain itu peneliti mampu menjelaskan secara komprehensif bagaimana aspek country of origin, animal cruelty, dan isu lingkungan terkait produk skincare menjadi pertimbangan utama dalam keputusan pembelian konsumen. Metode yang dipilih adalah deskriptif kualitatif. Instrumen utama penelitian kualitatif adalah peneliti yang terlibat langsung dengan subyek penelitian (Daymon \& Holloway, 2008)

Teknik pengumpulan data adalah teknik atau cara-cara yang dapat digunakan periset untuk mengumpulkan data (Pratiwi, 2019). Teknik pengumpulan data yang digunakan dalam penelitian adalah menyebar pertanyaan survey kepada perempuan milenial dan selanjutnya melakukan wawancara mendalam (in depth interview). Wawancara dilakukan terhadap informan yang telah dipilih menggunakan teknik purpossive sampling, yaitu informan ditentukan oleh kriteria-kriteria yang dibuat peneliti berdasarkan tujuan penelitian (Kriyantono, 2012a, 2012b). Kriteria pertama adalah perempuan milenial yang mengonsumsi produk skincare, karena subjek kajian dalam penelitian adalah terkait penggunaan produk skincare pada perempuan milenial. Perempuan milenial yang ada pada penelitian ini adalah mereka yang ada pada kategori usia 20-35 tahun. Hal ini sesuai dengan Indonesia milenial report, usia tersebut adalah kelompok umur penduduk milenial (Utomo et al., 2012)

Peneliti juga menyebar pertanyaan tertutup (survey) yang dijawab oleh 35 responden yang mempunyai kriteria informan penelitian dan selanjutnya dilakukan wawancara mendalam pada tiga informan kunci. Informan pertama adalah Amalia, berusia 21 tahun, berasal dari Malang dan sedang menempuh pendidikan di Universitas dengan jenjang pendidikan Strata 1. Informan kedua Novita, atau biasa dipanggil Ita berusia 23 tahun dan juga seorang mahasiswa Strata 1 di perguruan tinggi di Malang. Informan terakhir adalah Yani, 31 tahun. Yani adalah karyawan swasta yang mempunyai latar belakang pendidikan D1, selain bekerja Yani juga sedang melanjutkan jenjang pendidikan Strata 1.

Teknik analisis data berupa (1) kondensasi data, tahap ini peneliti melakukan pembacaan pada data yang telah diperoleh di lapangan dengan melakukan seleksi, menentukan fokus, menyederhanakan, dan mentransformasikan data dari jawaban wawancara penelitian, (2) penyajian data, merupakan tahapan di mana 
data yang sudah diseleksi diorganisir untuk mengarah pada menarik kesimpulan. Data yang telah diseleksi disajikan di dalam laporan penelitian dan dianalisis dengan konsep, (3) kesimpulan sebagai tahap akhir dari proses analisis data. Peneliti melakukan interpretasi data, memberikan penjelasan dan bahkan proposisi (Miles, 2015).

\section{HASIL DAN PEMBAHASAN}

Penelitian ini melakukan prasurvey penelitian dengan menyebar kuesioner berbentuk survey untuk mendapatkan gambaran umum terkait bagaimana perempuan milenial mendeskripsikan persepsi dan preferensi keputusan pembelian produk skincare. Konsumen, dalam hal ini perempuan milenial yang diperoleh dari survey sebanyak 35 orang, sebagian besar $(62,9 \%)$ menyatakan bahwa skincare merupakan produk yang sangat penting bagi perempuan (gambar 4.1). dari grafik tersebut menunjukkan bahwa skincare bisa masuk pada kebutuhan primer bagi

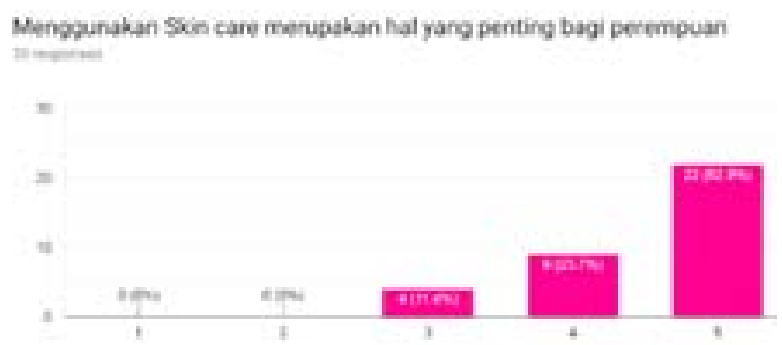

Sumber: Data primer penelitian, diolah peneliti, 2019 perempuan dalam hal merawat tubuh atau identitas visualnya.

Konteks yang menjadi alasan pembelian informan terdiri dari serangkaian proses dan faktor. Termasuk waktu pembelian, pengalaman menggunakan, gaya hidup, tahap kehidupan, pengaturan pola hidup, dan pola kerja.

Pertanyaan selanjutnya fokus pada preferensi dan persepsi akan kualitas sebagai dasar pertimbangan pada pembelian konsumen. Temuan yang menarik adalah saat konsumen perempuan milenial menyatakan bahwa aspek Country of origin bukan hal terlalu penting. Hasil ini berbanding terbalik ketika peneliti menanyakan terkait merek skincare yang mereka gunakan, mayoritas perempuan milenial menggunakan produk dengan merek bukan dari lokal/dalam negeri.

Dari gambaran awal terlihat faktor harga masih menempati alasan pertimbangan tertinggi dalam memutuskan pembelian skincare (gambar 4.2). Pada gambar terlihat lebih dari 50\% konsumen perempuan Milenial sangat

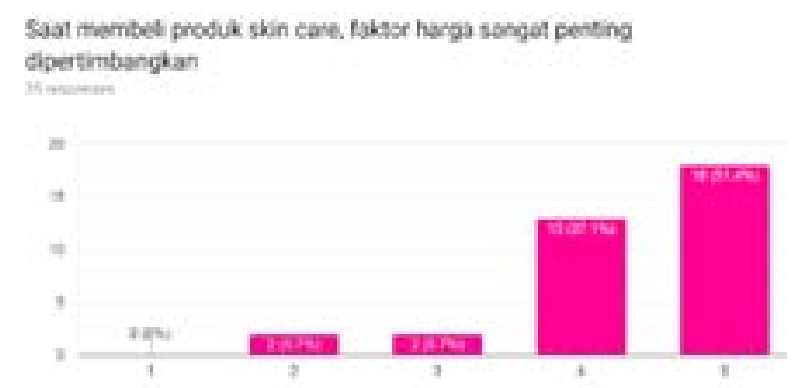

Sumber: Data penelitian diolah peneliti, 2019

Gambar 3 Faktor Harga 


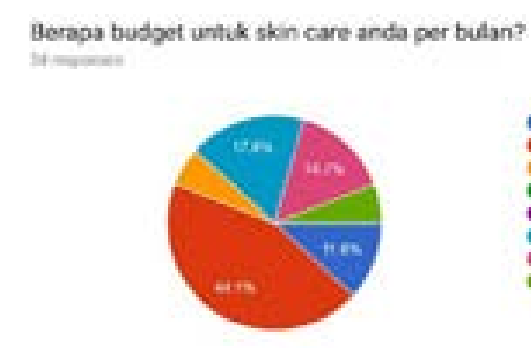

Sumber: Data penelitian diolah peneliti, 2019

\section{Gambar 4 Anggaran Pembelian Skincare}

setuju bahwa dalam membeli skincare mereka mempertimbangkan harga terlebih dahulu.

Pentingnya faktor harga ini juga terlihat dari bagaimana perempuan milenial menetapkan anggaran untuk pembelian skincare. Mayoritas sebanyak $44,1 \%$ perempuan milenial menetapkan anggaran sebesar 100.000 500.000 untuk membeli skincare (Gambar 4.3)

Berdasarkan hasil prapenelitian berupa survey untuk memetakan gambaran umum konsumsi produk skincare pada perempuan milenial, peneliti melakukan penelitian untuk mendapatkan data komprehensif dengan melakukan wawancara mendalam. Hasil wawancara menemukan bahwa pada tataran kebutuhan akan skincare masingmasing informan menyatakan bahwa skincare merupakan produk yang penting dan melewati beberapa proses untuk sampai pada preferensi produk yang akan mereka beli.

Produk skincare merupakan produk yang memiliki pemaknaan yang signifikan bagi konsumen. Semua informan setuju bahwa kondisi fisik seseorang merupakan representasi akan identitas diri seseorang. Hal ini juga sesuai dengan konsep budaya visual konsumen Pada teori corporal theory of body dinyatakan bahwa tubuh merupakan ekspresi paling tampak dan diartikan sebagai presentasi interpersonal dalam aktivitas sosial Pentingnya presentasi interpersonal ini juga menjelaskan perilaku konsumen dalam hal makan, berpakaian, dan pemakaian make up, termasuk skincare.

Menurut Mulyadi Nitisusastro dalam bukunya yang berjudul Perilaku Konsumen dalam Perspektif Kewirausahaan, dalam spektrum pertimbangan pembelian oleh konsumen yaitu meliputi pertimbangan rasional dan pertimbangan emosional (Nitisusastro, 2012). Memprioritaskan penampilan visual menjadi salah satu pertimbangan yang rasional dan emosional pada informan, dengan kondisi fisik yang sehat dan menarik membuat informan merasa lebih percaya diri ketika harus berkomunikasi dengan orang lain.

Pertimbangan rasional lain adalah bagaimana informan menekankan pada aspek kesehatan, misalnya cocok tidaknya komposisi produk pada kulitinforman. Sebelum melakukan pembelian salah satu informan memulai proses pembelian dengan membuka informasi pada laman resmi untuk mendapatkan ulasan produk dari konsumen lain. Informan Itha mengaku 
memilih membeli produk Inisfree berdasarkan informasi yang ia peroleh dari ulasan konsumen lain. semakin banyakulasan positifmembuat Itha memberikan persepsi positif dan menentukan preferensinya pada produk tersebut.

Proses yang sama juga ditemukan pada jawaban informan lainnya, Amalia dan Yani. Rekomendasi dari orang terdekat seperti teman juga mempengaruhi persepsi positif pada produk. Apabila ulasan atau informasi yang diperoleh sesuai dengan hasil yang mereka dapatkan maka mereka akan menjadi konsumen yang loyal. Namun, apabila fitemukan ketidakcocokan informan cenderung memulai kembali proses pencarian informasi, mempersepsi dan memutuskan pembelian.

Berdasarkan jawaban informan-informan tersebut terlihat alasan pembelian skincare melewati proses pertimbangan rasional. Konsumen menggunakan atribut produk sebagai dasar untuk mengevaluasi suatu produk, dan atribut-atribut itu menjanjikan manfaat yang dicari konsumen ketika membeli suatu produk

Proses inti dalam pengambilan keputusan konsumen adalah proses integrasi yang digunakan untuk mengkombinasikan pengetahuan untuk mengevaluasi dua atau lebih perilaku alternatif dan memilih satu diantaranya. Pada tahap ini konsumen dihadapkan pada suatu pilihan untuk melakukan pembelian atau tidak yang dapat didasari melalui tiga indikator
(Getricia, 2012).

Indikator pertama adalah aspek keyakinan konsumen pada produk, konsumen mempertimbangkan aspek kegunaan atau fungsi dari produk. Pemilihan merek pada hasil penelitian ditemukan informan cenderung memilih merek besar yang sudah terkenal.

"Sebenernya yang paling sering saya liat itu dari femaledaily. Kalo femaledaily kan banyak reviewnya. kalo saya ngeliat lagi dari Femaledaily atau Sociola kan suka bikin review tuh dari orang-orangnya. Terus di Youtube juga kan Youtuber dan sebagianya jadi saya liat Suhay Salim sih kalo Youtuber. Saya cocok banget sama skincare dia" (Amalia, wawancara offline, 20 Agustus 2019).

Indikator selanjutnya adalah kebutuhan akan suatu produk, selain keyakinan akan brand besar, aspek kebutuhan juga menjadi hal yang dipertimbangkan. Aspek kebutuhan disini lebih pada bagaimana skincare mampu menjawab dari keinginan informan, misalnya kebutuhan akan kulit mereka, atau masalah kulit yang perlu diatasi.

Indikator ketiga adalah keinginan membeli produk. Indikator ini tidak terlalu tampak pada hasil penelitian, informan lebih menitikberatkan pada kebutuhan akan produk dalam melakukan pembelian, bukan hanya pada aspek keinginan. Berdasarkan hasil wawancara ketiga informan, perempuan milenial ini bukan termasuk pada konsumen yang impulsif atau membeli hanya karena faktor keinginan. Konsumen impulsif dapat dianalogikan sebagai proses pembelian 
tanpa perencanaan. Konsumen terpapar informasi yang mendorong mereka membeli barang yang sebenarnya tidak dibutuhkan dan apakah barang tersebut memenuhi kebutuhan mereka (Kumar, 2013) Informan menyatakan mereka akan mempertimbangkan terlebih dahulu dari segi harga, manfaat, dan kebutuhan akan kulitnya. Pertimbangan ini disebabkan karena kondisi keuangan informan yang masih berasal dari orang tua.

Perilaku konsumen merupakan perilaku yang ditampilkan dalam pencarian, pembelian, penggunaan, evaluasi dan penghapusan produk dan layanan yang diharapkan dapat memenuhi kebutuhan konsumen (Schiffman, 2010). Perilaku dari konsumen individu dan keluarga atau rumah tangga membuat keputusan untuk menghabiskan sumber daya yang tersedia (waktu, uang, usaha) pada produk yang mereka konsumsi. Kegiatan tersebut meliputi apa yang mereka beli, mengapa, kapan, dan di mana mereka membelinya, serta seberapa sering mereka menggunakannya.

Berdasarkan konsep di atas pada konsumen produk skincare juga melewati tahapan mencari, membeli, menggunakan dan mengevaluasi. Prosesnya lebih pada pertimbangan aspek kegunaan. Produk skincare fokus pada kebutuhan individu, di mana individu sepenuhnya yang membuat keputusan pembelian.
Padapenelitianiniditemukanbahwapersepsi akan kualitas yang menjadi pertimbangan konsumen membeli dan menggunakan skincare adalah pada identitas brand. Brand yang dipilih mayoritas merupakan brand yang sudah terkenal dan banyak memiliki catatan ulasan, sehingga konsumen akan mendapatkan informasi yang cukup akan produk. Persepsi akan kualitas biasa disebut dengan perceived quality; perceived quality adalah persepsi akan kualitas atau keunggulan produk yang ada di benak konsumen (Listiana, 2012) Persepsi akan kualitas dari konsumen akan keunggulan produk merupakan inti dari kerangka ekuitas merek. Hal ini menjadi alasan konsumen untuk membeli produk dan memungkinkan produk untuk melakukan diferensiasi dengan produk pesaingnya.

Penggunaan brand ambasador menjadi salah satu yang ikut dipersepsi informan. Pada hasil wawancara dengan Amalia, ia menyatakan bahwa alasan ia membeli sebuah produk toner berdasarkan persepsi positif yang ada pada brand ambassador produk. Brand ambassador menjadi salah satu aspek ekstrinsik yang menjadi pertimbangan bagaimana konsumen melakukan persepsi akan kualitas produk dan memutuskan pembelian.

Aspek ekstrinsik lain yang bisa ditemui pada skincare adalah isu akan country of origin dan animal cruelty. Pada dasarnya, citra negara 
dalam perspektif pemasaran dapat didefinisikan pada tiga tingkat, yaitu : overall country image, aggregate product country image, dan specific product country image. Namun, pada hasil penelitian, aspek negara asal produk tidak menjadi pertimbangan utama sebagai preferensi dalam memutuskan pembelian. Informan lebih memberikan prioritas pada aspek kebutuhannya tanpa melihat faktor lain (Demirbag et al., 2010).

Persepsi akan country of origin (COO) merupakan asosiasi mental dan keyakinan yang dipicu oleh suatu negara (Kotler \& Keller, 2012). Pemasar juga memperhatikan terkait sikap dan persepsi konsumen akan asal negara suatu produk. COO sendiri merupakan salah satu asumsi ekstrinsik yang mempengaruhi konsumen dalam memutuskan pembelian, salah satunya pada produk skincare.

Terkait brand yang mereka pilih mayoritas adalah brand dari Korea dikarenakan produk dari negara ini sedang banyak digunakan oleh pengguna skincare. Data penelitian yang menunjukkan bahwa Korea menjadi negara asal skincare yang paling banyak dipakai juga disebabkan karena adanya tren K-pop dan K-drama. Tren perawatan kulit dan makeup Korea muncul sebagai sub-kategori budaya konsumen Korea. K-beauty adalah istilah umum untuk semua perawatan kulit, produk rias yang diimpor dari Korea Selatan (Kwon, 2018)
Industri kecantikan korea telah tumbuh dalam ekspor ke pasar global. Menurut International Trade Administration (2017) total ekspor kosmetik Korea pada tahun 2016 adalah sekitar USD 4,2 miliar, yang menunjukkan peningkatan $61,6 \%$ dari tahun sebelumnya menurut Asosiasi Pedagang Farmasi Korea.

Google Trends menggambarkan bahwa pencarian makeup Korea dan perawatan kulit Korea telah mengalami peningkatan yang stabil sejak 2010 sebagai kata pencarian. Pada penelitian, faktor $\mathrm{COO}$ belum menjadi faktor utama, namun para informan menyadari bahwa mereka aware dengan isu tersebut. Faktor $\mathrm{COO}$ masih kalah dengan faktor kondisi apakah skincare tersebut sesuai dengan kebutuhan kulit mereka atau tidak.

Dibandingkan dengan faktor COO, proses pembelian yang dilakukan sebagian besar konsumen adalah mempertimbangkan faktor aroma sampai bagaimana fitur yang ada pada skincare. Tahapan awal biasanya mereka mencium produk, itulah sebabnya banyak skincare mengandung pewangi sintetis. Selain aroma, produk kecantikan dapat ditandai dengan fitur unik seperti daya serap, pelembab, penampilan pada kulit saat digunakan, tebal dan residu; karakteristik dan kinerjanya adalah hasil dari formulasi fisiknya. Atribut ini dapat menawarkan motif untuk dipilih satu produk skincare lebih 
dari yang lain.Proses ini merupakan salah satu bentuk dari bagaimana proses persepsi terjadi. Informan melakukan proses memilih, mengorganisasikan, mengartikan masukan informasi untuk menciptakan suatu gambaran akan produk. Informasi ini selanjutkan tertanan dalam memori informan dalam memberikan preferensi pada produk.

Informan juga mencoba mengendalikan kesehatan mereka dengan mencari produk perawatan kulit atau skincare yang sehat. Hal ini disebabkan, karena orang percaya bahwa bahan alami membuat produk kecantikan lebih baik dan lebih sehat, penggunaan istilah 'alami' pada label menjadi kekuatan pendorong utama penjualan. Isu sosial terkait komposisi produk menjadi faktor utama preferensi konsumen dalam memilih produk skincare. Selanjutnya, hasil menunjukkan bahwa konsumen yang memiliki persepsi positif terhadap produk tertentu memiliki niat lebih besar untuk membelinya daripada konsumen yang memiliki persepsi kurang positif. Serupa dengan harapan, pengaruh normatif ditemukan menjadi komponen penting untuk menentukan pembelian konsumen.

Isu yang menjadi pertimbangan selanjutnya adalah isu lingkungan seperti animal cruelty. Isu ini menekankan pada apakah perusahaan produsen skincare tersebut peduli kepada hewan. Apakah mereka melakukan tes uji coba pada hewan untuk memastikan produk aman. Itha, salah satu informan penelitian pernah menyatakan faktor ini pernah menjadi salah satu preferensinya dalam memilih sebuah skincare. Pesan persuasi bahwa skincare telah bebas animal cruelty menambah persepsi positifnya terhadap produk.

Hal serupa juga terjadi pada Amalia, hobi dan kegemarannya memelihara binatang juga yang menjadi faktor yang menyebabkan ia peka terhadap isu animal cruelty ini. Amalia akan cenderung memilih produk yang animal cruelty dibandingkan produk yang tidak peduli pada binatang. Apa yang disampaikan oleh Amalia ini merupakan salah satu gambaran konsep bahwa pengalaman individu menjadi faktor penentu akan persepsinya. Harapan mengenai bagaimana situasi, orang, atau peristiwa tertentu merupakan faktor penentu yang penting bagaimana stimuli tersebut kemudian dirasakan (Robbins, 2015). Adanya nilai sosial pada produk menciptakan sebuah keterlibatan situasional pada konsumen. Melakukan seleksi pemilihan produk yang sesuai dengan preferensi, maka konsumen merasa ikut terlibat pula dengan kepedulian sosial. Maka, dapat diartikan bahwa ketika konsumen membeli produk yang peduli akan lingkungan maka, ia juga telah melakukan perubahan sosial. Preferensi konsumen dapat diartikan dengan kesukaan, pilihan terhadap suatu hal yang 
lebih disukai konsumen. Preferensi ini muncul melalui proses persepsi konsumen terhadap sebuah produk (Wono, 2018).

Implikasi lain dari penelitian adalah bahwa konsumsi produk skincare bagi informan menjadi salah satu cara untuk mempertahankan penampilan dan simbo status sosial. Masingmasing informan berpendapat bahwa penampilan mereka setelang penggunaan skincare manjadikan mereka lebih percaya diri. Pada informan Yani, dalam wawancara menyebutkan bahwa sebelum menjadi konsumen skincare dia tidak percaya diri karena kulitnya yang lebih gelap dibandingkan temantemannya. Pada informan Itha dan Amalia menyampaikan bahwa perawatan pada wajah penting karena orang lain akan menilai kita dari penampilah fisik kita terlebih dahulu. Sehingga, menjadi penting bagi mereka untuk memberikan prioritas lebih pada produk skincare.

Kesadaran akan penampilan membuat konsumen tertarik pada produk yang mengekspresikan atau mengubah visualisai mereka. Konsumsi pribadi akan produk perawatan adalah perilaku pembelian yang memuaskan kebutuhan eksistensi konsumen. Penampilan seseorang merupakan salah satu bentuk komunikasi nonverbal yang ingin disampaikan konsumen. Produk skincare sangat erat kaitannya dengan identitas visual, konsumen perempuan milenial menyatakan bahwa produk skincare penting dalam menunjang penampilan mereka di publik. Skincare mampu menambah kepercayaan diri konsumen.

Konsumen sering memilih produk yang menunjukkan status mereka di masyarakat. Penilaian bahwa membeli barang dengan harga tinggi dan dari merek-merek terkenal akan mendapat pengakuan dari lingkungan sosial, sehingga menimbulkan kepercayaan diri yang tinggi. Konsumen percaya bahwa harga yang lebih tinggi menunjukkan kualitas yang lebih baik. Hal ini seperti yang disampaikan oleh informan Itha yang merasa produk non-lokal dengan harga lebih mahal menjadi preferensinya menentukan produk yang cocok.

Hal ini menunjukkan bahwa persepsi akan harga menjadi penentu kualitas produk, semakin tinggi harga produk makan kualitasnya juga semakin bagus. Pembelian barang berdasarkan fungsi simbolis yang terkandung dalam barang seperti itu umumnya dilakukan oleh seseorang hanya untuk meningkatkan status dalam diri mereka sendiri sehingga mereka akan mendapatkan pengakuan dari lingkungan sosial.

Salah satu dari manfaat yang ditawarkan oleh merek kepada konsumen adalah manfaat simbolis. Manfaat simbolis mengacu pada dampak psikologis yang akan diperoleh konsumen ketika dia menggunakan merek berarti merek akan mengkomunikasikan identitas konsumen. Manfaat simbolik berkaitan 
dengan kemampuan suatu produk dalam memberikan image bagi penggunanya. Manfaat simbolik dapat diukur berdasarkan estetika, identifikasi sosial, status, dan identitas personal (Ashtray, 2011).

Pada perkembangan selanjutnya merek adalah sebuah nama yang dianggap mewakili sebuah obyek, dianggap sebagai sebuah simbol kemudian menjadi image. Persepsi merek, yaitu memberikan penilaian pelanggan terhadap image sebuah produk dengan menilai dari segi kualitas merek atau arti bahwa produk tersebut mempunyai nilai atau kualitas tertentu. Persepsi merek merujuk pada persepsi konsumen terhadap nama atau simbol yang diasosiasikan dengan suatu produk/jasa dan menimbulkan arti psikologis. Merek memberikan arti bahwa produk dan jasa mempunyai nilai atau kualitas tertentu bagi konsumen.

\section{SIMPULAN}

Persepsi komunikasi konsumen merujuk pada bagaimana konsumen melakukan evaluasi terhadap skincare. Konsumen menekankan bahwa manfaat atau keuntungan yang diperoleh adalah komponen yang paling penting. Persepsi akan merek, komposisi, COO, animal testing, dan isu lingkungan mampu menimbulkan arti psikologis atau asosiasi tertentu.

Preferensi konsumen dalam menentukan keputusan pembelian produk skincare terdiri dari dua indikator, aspek keyakinan akan produk dan aspek kebutuhan akan produk. Aspek keyakinan meliputi pertimbangan identitas brand yang sudah punya "nama besar" dan banyak digunakan. Sedangan indikator kebutuhan ada pada bagaimana skincare tersebut dapat memenuhi kebutuhan terutama dalam mengatasi permasalahn kulit konsumen..

Rekomendasi untuk penelitian selanjutnya dapat lebih difokuskan lagi pada bagaimana brand sebuah skincare atau produk perawatan diri menjadi representasi identitas visual seseorang, atau menganti subjek penelitian pada konsumen lak-laki. Penelitian selanjutnya dapat diteliti salah satunya dengan metode fenomenologi.

\section{DAFTAR PUSTAKA}

Ashtray, T. (2011). How do consumers make their purchase decisions between genuine and counterfeit products? Canada: The University of Guelph.

Cresswell, J. W. (2013). Research design: pendekatan kualitatif, kuantitatif, dan mixed. Cetakan ke-3. Terjemahan Achmad Fawaid. Yogyakarta: Pustaka Pelajar.

Daymon, C., \& Holloway, I. (2008). Metode - metode riset kualitatif dala public relations dan marketing communications. Yogyakarta: Penerbit Bentang.

Demirbag, M., Sahadev, S., \& Mellahi, K. (2010). Country image and consumer preference for emerging economy products: the moderating role of consumer materialism. International Marketing 
Review, 27, 141-163. https://doi. org/10.1108/02651331011037494

Getricia, W. D. (2012). Analisis faktorfaktor yang mempengaruhi keputusan pembelian konsumen pada produk minuman berisotonik pocari sweat. Jurnal Manajemen.

Kavaratzis, M. (2009). What can we learn from city marketing practice. European Spatial Research and Policy Journal, 16.

Kotler, \& Keller. (2012). Manajemen pemasaran. Edisi 12. Jakarta: Erlangga.

Kriyantono, R. (2012a). Teknik praktis riset komunikasi, disertai contoh praktis riset media, public relations, advertising, komunikasi organisasi, komunikasi pemasaran. Jakarta: Kencana Prenada Media Group.

Kriyantono, R. (2012b). Teknik praktis riset komunikasi. Jakarta: Prenada Media.

Kumar, R. (2013). Marketing and branding”: Indian Scenario. Pearson Education.

Kwon, Y. J. (2018). The emergence of k-beauty: rituals and myths of Korean skin care practice. International Textile and Apparel Association (ITAA) Annual Conference Proceedings, 33. Cleveland: Iowa University.

Larosche, M. (2005). The influence of country image structure on consumer evaluations of foreign products. International Marketing Review, 96-115.

Listiana, E. (2012). Pengaruh country of origin terhadap perceived quality dengan moderasi etnosentris konsumen. Jurnal Administrasi Bisnis, 25-51.

Miles, M. B. (2015). Qualitative data analysis. California. California: Sage Publication.

Neuman, W. (2014). Social research methods: qualitative and quantitative approaches. In teaching sociology (vol. 30). https://doi. org/10.2307/3211488

Nitisusastro. (2012). Perilaku konsumen dalam perspektif kewirausahaan. Bandung: Alfabeta.

Pangestuti, A., \& Devika, E. (2018). Pengaruh country of origin terhadap brand image dan dampaknya bagi keputusan pembelian (survey online pada konsumen skin care etude house di Indonesia). Jurnal Administrasi Bisnis, 110-118.

Peter, J. P. (2013). Perilaku konsumen dan strategi pemasaran. Jakarta: Erlangga.

Phau, I. G. (2010). Conceptualizing the country of origin of brand. Journal Of Marketing Communications, 159-170.

Pratiwi, S. R. (2019). Manajemen kampanye komunikasi kesehatan dalam upaya pengurangan prevalensi balita stunting. Jurnal Manajemen Komunikasi, 4(1), 1-19. https://doi.org/0.24198/jmk.v4i1.23435

Priyandana, A. (2018). Perilaku konsumen digital di Indonesia. Retrieved from Mmrketing.co.id website: https:// marketing.co.id/perilaku-konsumendigital-indonesia/

Putra, I. ., \& Ghozali, H. (2018). Pengaruh iklan untung beliung bri britama di televisi terhadap keputusan konsumen dalam menabung. Wacana, 82-90.

Robbins, S. P. (2015). Perilaku organisasi (organizational behavior), Terj.Ratna Saraswati dan Febriella Sirait Edisi 16. Jakarta: Salemba Empat.

Schiffman, L. (2010). Consumer behavior. New Jersey: Prentice Hall Inc.

Shilling, C. (2007a). Sociology and the body; classical traditions and new agendas. The Sociological Review, 1-18.

Shilling, C. (2007b). The body and social theory, 2nd ed. London: Sage Publication.

Shimp, T. A. (2014). Komunikasi pemasaran 
terpadu dalam periklanan dan promosi. Jakarta: Salemba Empat.

Shree, K., \& Nagabushanam, M. (2018). Consumer behavior in new digital era: a paradigm shift. International Journal of Management Studies, 5(3), 60-70.

Simamora, B. (2008). Panduan riset perilaku

konsumen. Jakarta: Gramedia Pustaka Utama.

Suryana, A., Zein, D., Sumartias, S., \& Gemiharto, I. (2019). Pengaruh strategi komunikasi pemasaran, budaya organisasi, karakteristik individu inovatif dan komitmen organisasional terhadap kinerja usaha kecil dan menengah. Jurnal
Manajemen Komunikasi, 3(2), 185-201.

Utomo, W. O., Lubis, U. Z., \& Sudradjat, S. A. (2012). Indonesia millenial report 2019. Jakarta: IDN Research Institute.

Westmoreland, C., \& Holmes, A. M. (2009). Assuring consumer safety without animals. Organogenesis, 67-72.

Wono, H. Y. (2018). Preferensi mahasiswa terhadap marketing. Jurnal Komunikasi Profesional, 62-75.

ZAP Beauty Index. (2018). Hasil survey zap beauty index terkait industri kecantikan. Retrieved from https://www.kirani.id/hasilsurvey-zap-beauty-index-terkait-industrikecantikan/ 